\title{
Cotton and Soil Responses to Annual Potassium Fertilization Rate
}

\section{Morteza Mozaffari}

Soil Fertility/Soil Testing, Northeast Research and Extension Center, University of Arkansas System Division of Agriculture, Keiser, AR, USA

Email:mmozaff@uark.edu

How to cite this paper: Mozaffari, $M$. (2018) Cotton and Soil Responses to Annual Potassium Fertilization Rate. Agricultural Sciences, 9, 765-775.

https://doi.org/10.4236/as.2018.96054

Received: January 1, 2018

Accepted: June 26, 2018

Published: June 29, 2018

Copyright (c) 2018 by author and Scientific Research Publishing Inc. This work is licensed under the Creative Commons Attribution International License (CC BY 4.0).

http://creativecommons.org/licenses/by/4.0/

\begin{abstract}
The objective of this study was to evaluate the effect of potassium $(\mathrm{K})$ fertilization rate $(0,27.9,56.4,84.7,112.9$, and $141.1 \mathrm{~kg} \mathrm{~K} / \mathrm{ha})$ and cotton (Gossypium hirsutumn L.) cultivars of slightly differing maturity on seedcotton yield and Mehlich-3 soil-test $\mathrm{K}$ concentrations. The cotton cultivars "Stoneville 4892" and "Stoneville 5599" represented long-season cultivars while "Paymaster 1218" and "Deltapine 444" represented early-season cultivars. The same $\mathrm{K}$ fertilizer treatments were applied to the same plots during the three years of the study. Higher order interactions of cropping year, cotton cultivar and $\mathrm{K}$-fertilization rates were not significant $(P \geq 0.50)$, indicating the two cultivars of slightly different maturity respond similarly to K-fertilization. Cropping year and K-fertilizer application rates significantly affected seedcotton yield $(P<0.0001)$. Potassium fertilization did not significantly influence seedcotton yield in the first year but significantly increased seedcotton yield in second and third year $(P \leq 0.0074)$, as well as 3 -year average, and total seedcotton yields $(P \leq 0.0006)$. Seedcotton yields ranged from 3418 to 4127 $\mathrm{kg} \cdot \mathrm{ha}^{-1}$ and 2980 to $3487 \mathrm{~kg} \cdot \mathrm{ha}^{-1}$ in the second and third year respectively while 3-year average and total seedcotton yields were 2943 to 3443 and 8832 to $10,330 \mathrm{~kg} \cdot \mathrm{ha}^{-1}$. The relation between annual, 3-year average, and total $\mathrm{K}$ application rates and seedcotton yield was linear $\left(\mathrm{R}^{2} \geq 0.82, P \leq 0.0125\right)$. Potassium fertilization significantly increased post-harvest (fall) Mehlich-3 extractable soil $\mathrm{K}$ in all three years $(P \leq 0.0002)$. This study indicated that, in a representative Mississippi River Delta silt loam soil, when Mehlich-3 extractable $\mathrm{K}$ was $<98 \mathrm{mg} \cdot \mathrm{kg}^{-1}$, $\mathrm{K}$ fertilization was needed to increase seedcotton yield and prevent soil $\mathrm{K}$ depletion. This supports the current University of Arkansas fertilizer recommendations for irrigated cotton production, where application of $56 \mathrm{~kg}$ of $\mathrm{K} \mathrm{ha}^{-1}$ is recommended to optimize seedcotton yield and prevent soil $\mathrm{K}$ reserve depletion when Mehlich-3 extractable soil test $\mathrm{K}$ is medium (91- $130 \mathrm{mg} / \mathrm{kg}$ ).
\end{abstract}




\section{Keywords}

Cotton, Potassium, Mehlich-3, Soil Test

\section{Introduction}

Cotton (Gossypium hirsutumn L.) is a major row crop in Southeast United States and world. In 2010, more than 218,000 hectares of cotton were harvested in Arkansas with an annual estimated value of \$414 million [1]. More than 99\% of the Arkansas cotton crop is produced in the Mississippi River Delta Region of Arkansas (MRDRA) where most soils are formed from Mississippi River Valley alluvium and the predominant soil texture is silt loam. These low cation exchange capacity soils have been supporting intensive cotton production for more than a century making supplemental nutrient application necessary for producing high-yielding cotton.

Potassium (K) plays an important role in many physiological processes in cotton [2] [3]. Potassium is required for regulating the stomatal opening and closing [4], maintaining leaf turgor pressure [5], and photosynthesis [6]. Cotton demand for $\mathrm{K}$ is particularly high during fruit development [7]. Potassium accumulation rates for irrigated cotton during high crop demand can be as high as $2.8 \mathrm{~kg} \mathrm{~K} \mathrm{ha}^{-1}$ day $^{-1}$ [2]. Cotton is described as being more sensitive to $\mathrm{K}$ deficiency than other row crops [2] [8] making $\mathrm{K}$ deficiency a serious threat to yield potential and lint quality. Pettigrew et al. [9] reported K deficiency reduced cotton lint yield, boll mass, and fiber micronair by $9 \%, 5 \%$, and $10 \%$, respectively. In Arkansas, Maples and Keogh [10] reported a 21\% yield increase from annual application of $84.7 \mathrm{~kg} \mathrm{~K} \mathrm{ha}^{-1}$ to cotton grown in a sandy loam with $90 \mathrm{mg} \cdot \mathrm{kg}^{-1}$ $\mathrm{NH}_{4} \mathrm{OAc}$ extractable $\mathrm{K}\left(\sim 90 \mathrm{mg} \cdot \mathrm{kg}^{-1}\right.$ Mehlich-3 extractable $\mathrm{K}$ or Medium soil-test $\mathrm{K}$ according to current University of Arkansas recommendations). Howard et al. [11] reported the 3-year average lint yield in a soil testing low in $\mathrm{K}$ of $321 \mathrm{~kg} \cdot \mathrm{ha}^{-1}$ for cotton receiving no $\mathrm{K}$ and $924 \mathrm{~kg} \cdot \mathrm{ha}^{-1}$ for cotton receiving 84.7 $\mathrm{kg} \mathrm{K} \mathrm{ha}{ }^{-1}$, an average yield increase of $89 \%$. These examples demonstrate the importance of supplemental $\mathrm{K}$ application for obtaining a high cotton yield in MRDRA.

The state-average cotton yield in Arkansas had increased from $670 \mathrm{~kg} \cdot \mathrm{ha}^{-1}$ in 1976 to $1170 \mathrm{~kg} \cdot \mathrm{ha}^{-1}$ in 2010 [12] (Arkansas Agricultural Statistics Service, 2017) because of the introduction of fast-fruiting cultivars, improvements in pest management, and irrigation and other technological advancements. Modern cotton cultivars produce higher yields and develop their boll load over a shorter period compared with obsolete cotton cultivars [13] [14]. The greater yield potential of modern cotton cultivars requires more intensive management of soil and fertilizer nutrients to ensure that the high genetic potential can be realized. Consequently, between 1990 and 2010, the average potash application rate in Arkansas increased from 58 to $72 \mathrm{~kg} \cdot \mathrm{ha}^{-1}$. These statistics indicate that the pro- 
ducers have recognized the importance of proper $\mathrm{K}$ nutrition for sustaining soil productivity and high yields. Despite the improvements in cotton yield potential and production practices, soil-test based K-fertilizer recommendations for cotton have changed very little because of limited data from replicated field experiments. Thus, current recommendations reflect the cultivars, soil fertility status, and management practices established and used in the 1980's and 1990's.

Soil test-based $\mathrm{K}$ fertility recommendations should periodically be evaluated and verified and if needed, modified to ensure their accuracy. Improving $\mathrm{K}$-fertility recommendations will ensure that the growers receive a sound return on fertilizer investments and promote economic and agronomic sustainability of cotton production. The objectives of this 3-year field experiment were to evaluate the effect of $\mathrm{K}$-fertilization rate and cotton cultivar on: 1) seedcotton yield, and 2) Mehlich-3 extractable $K$ under contemporary production practices in a soil representative of cotton production soils in MRDRA.

\section{Material and Methods}

A 3-year replicated field experiment was conducted on a Convent silt loam (coarse-silty, mixed, thermic Fluvaquentic Endoaquepts) at the University of Arkansas Lon Mann Cotton Research Station (LMCRS) in Marianna, Arkansas from 2004-2006. The Convent soil is an alluvial silt loam typical of soils used for irrigated-cotton production in MRDRA. The research area was planted in grain sorghum (Sorghum bicolor L.) in 2003. In the spring 2004, prior to application of any soil amendments, plot boundaries were established and a composite soil sample consisting of six soil cores was collected from the 0 -to $15-\mathrm{cm}$ soil depth of each replication. Soil samples were oven dried at $65^{\circ} \mathrm{C}$, crushed, extracted with Mehlich-3 solution [15] and the elemental concentrations in the extract were measured by inductively coupled plasma atomic emission spectroscopy. Soil $\mathrm{pH}$ was measured in a 1:2 (weight: volume) soil-water mixture extraction and soil organic matter was measured by weight loss on ignition [15] Soil texture was determined by the hydrometer method [16].

The experiment was a randomized complete block with a split-split-plot treatment structure where cotton cultivar was the main-plot factor, $\mathrm{K}$ rate $(0$, 28.2, 56.4, 84.7, 112.9, and $141.1 \mathrm{~kg} \mathrm{~K} \mathrm{ha}^{-1}$ ) was the subplot factor, and year was the sub-sub-plot factor. Each year, two commonly used cultivars, which differed slightly in relative maturity, were used in the study. "Stoneville 4892" and "Stoneville 5599" represented long-season cultivars while "Paymaster 1218" and "Deltapine 444" represented early-season cultivars. "Stoneville 4892" and "Paymaster 1218" were planted on 12 May in 2004; "Stoneville 4892" and "Delta Pine 444" were planted on 5 May 2005; and "Stoneville 5599" and "Delta Pine 444" were planted on 22 May in 2006. Cotton seeding rate was uniform across years and cultivars at 50,000 seeds $\mathrm{ha}^{-1}$. Each experimental treatment was replicated four times. There were a total of 48 of experimental plots each year. In the second and third years of the study the same $\mathrm{K}$ rates were applied to the same 
plots as the first year. Muriate of potash fertilizer $(0-0-67, \mathrm{~N}, \mathrm{P}, \mathrm{K})$ was surface applied in a single or two split applications. In 2004, all $\mathrm{K}$ rates $\leq 112 \mathrm{~kg} \mathrm{~K} \mathrm{ha}^{-1}$ were surface applied post-emergence on 16 July and the balance of $\mathrm{K}(28.2 \mathrm{~kg} \mathrm{~K}$ $\mathrm{ha}^{-1}$ for $141.1 \mathrm{~kg} \mathrm{~K} \mathrm{ha}^{-1}$ treatment) was broadcast on 3 Aug. In 2005 all $\mathrm{K}$ rates $\leq$ $84.7 \mathrm{~kg} \mathrm{~K} \mathrm{ha}^{-1}$ were surface applied post emergence on 17 May and the balance of $\mathrm{K}\left(28.2\right.$ and $56.4 \mathrm{~kg} \mathrm{~K} \mathrm{ha}^{-1} \mathrm{~K}$ for 112.9 and $141.1 \mathrm{~kg} \mathrm{~K} \mathrm{ha}^{-1}$ treatments, respectively was broadcast on 30 June. Plots were irrigated to incorporate $\mathrm{K}$ fertilizer after each application. In 2006, the entire amount of each K-rate was applied preplant and incorporated shallowly by a do-all before reshaping beds for planting. Each plot was 14-m long and 4.6-m wide allowing for four rows of cotton with $96.5-\mathrm{cm}$ wide row spacing. Fall tillage operations consisted of mowing cotton stalks, disking, and hipping the rows and were followed by spring tillage of re-hipping and rolling the beds before planting. Cotton received a total of $102 \mathrm{~kg}$ $\mathrm{N} \mathrm{ha}{ }^{-1} \cdot \mathrm{year}^{-1}$. The first $22 \mathrm{~kg} \cdot \mathrm{ha}^{-1} \mathrm{~N}$ was applied as ammonium sulfate preplant or within one week after planting and the balance of $\mathrm{N}$ was applied as urea at first square or shortly after and incorporated with irrigation. Triple superphosphate (0-52-0) was surface applied to supply $22.6 \mathrm{~kg} \mathrm{P} \mathrm{ha}^{-1}$ (46 lbs $\mathrm{P}_{2} \mathrm{O}_{5} /$ acre) before planting and incorporated with a do all every year. Boron was foliar applied several times with insecticides to supply total of $0.6 \mathrm{~kg} \mathrm{~B} \mathrm{ha}^{-1} \cdot \mathrm{year}^{-1}(0.5 \mathrm{lbs}$ $\mathrm{B} / \mathrm{acre} / \mathrm{year}$ ). Pest management practices closely followed the University of Arkansas recommendations for irrigated-cotton production to ensure yield was not affected by pest damage. Irrigation timing was managed by the University of Arkansas Cooperative Extension Service Irrigation Scheduler program [17].

Each year the two center rows of each plot were harvested with a plot spindle picker equipped with electronic weight recording instruments that measured seedcotton yield. In the fall of 2004 after cotton harvest, six soil cores were collected randomly from the 0 to $15.2-\mathrm{cm}$ depth within each plot, composited (i.e., by plot) and processed as described previously. The same procedure was repeated in the spring of 2005 and 2006 before annual application of $\mathrm{K}$ fertilizer and the fall of 2005 and 2006 after cotton harvest.

Analysis of variance (ANOVA) was performed using the PROC MIX procedure of SAS and a treatment effect was declared significant when $P \leq 0.1$. Seedcotton yield data and post-harvest Mehlich-3 extractable soil test $\mathrm{K}$ were analyzed as a split-split design where cotton cultivar was the main plot treatment, $\mathrm{K}$-rate was the subplot treatment and year was the sub-subplot factor. This allowed us to evaluate the change in yield and soil test $\mathrm{K}$ at each $\mathrm{K}$-rate across the time. When applicable the relationship between mean of response variables (seedcotton yield, soil test $\mathrm{K}$ ) and $\mathrm{K}$ application rate was ascertained by regression analysis. Cumulative 3-year seedcotton yield data were analyzed as a split-plot design. When appropriate, mean separations were performed by the minimum significant difference (MSD) test at significance levels of $P=0.1$. 


\section{Results and Discussion}

In the spring of 2004 the preplant mean soil $\mathrm{pH}$ was 6.0 , soil organic matter was $1.6 \%$, sand content was $11 \%$, and clay content was $25 \%$. During the study, soil $\mathrm{pH}$ changed very little and Mehlich-3 extractable P ranged from 33 to $40 \mathrm{mg} \cdot \mathrm{kg}^{-1}$ which is interpreted as "Medium" to "Optimum" levels of soil P (Table 1) according to the current University of Arkansas guidelines for soil test interpretation. Concentration of other nutrients was typical of agricultural soils in MRDRA. The initial Mehlich-3 extractable $\mathrm{K}$ averaged $105 \pm 8 \mathrm{mg} \cdot \mathrm{kg}^{-1}$, which was interpreted as "Medium" (91 - $130 \mathrm{mg} \cdot \mathrm{kg}^{-1}$, [18] Espinoza et al., 2006) for cotton production in Arkansas. By definition, in the absence of $\mathrm{K}$ fertilization, crop yields would be expected to be $85 \%$ - $95 \%$ of maximum potential if $\mathrm{K}$ fertilizer were not applied, however $56 \mathrm{~kg} \cdot \mathrm{ha}^{-1} \mathrm{~K}$ would have been recommended to ensure production of maximal yields and replace $\mathrm{K}$ removed by harvested cotton to maintain the soil-test $\mathrm{K}$. Soil-test $\mathrm{K}$ of the unfertilized control $(0 \mathrm{~K})$ plots, averaged $97 \mathrm{mg} \cdot \mathrm{kg}^{-1}$ (Medium) in 2005 and $90 \mathrm{mg} \cdot \mathrm{kg}^{-1}$ (Low) in 2006, showing a gradual decline across time in the absence of $\mathrm{K}$ fertilization.

\subsection{Seedcotton Yield Response to Year, K-Rate and Cotton Cultivar}

Cotton cultivar $(\mathrm{C})$, Cultivar $\times \mathrm{K}$-rate $(\mathrm{C} \times \mathrm{KR}), \mathrm{C} \times \mathrm{Year}(\mathrm{C} \times \mathrm{Y}), \mathrm{KR} \times \mathrm{Y}, \mathrm{C} \times$ $\mathrm{KR} \times \mathrm{Y}$ did not significantly $(P>0.1)$ influence seedcotton yield (Table 2$)$. Mullins et al. [19] evaluated the seedcotton response of a short season and a long season cotton cultivar to $\mathrm{K}$ fertilization and did not find a significant difference between the two cultivars. The Arkansas cotton variety trials [20] conducted at the same location as our test, did not show any significant yield difference between the two cultivars of varying maturity that we used in this study. Clement-Bailey and Gwathmey [21] evaluated cotton response in a no-tilled Loring silt loam (thermic Oxy Aquatic Fragiudalf) and reported a yield difference between two cotton cultivars of contrasting maturity only in one out of 3 years. The non-significant $\mathrm{C} \times \mathrm{KR}$ effect in this study is in agreement with other work in the region such as Pettigrew et al. [9]; Pettigrew and Meredith [22],

Table 1. Selected chemical property means for soil samples collected from the $0-15 \mathrm{~cm}$ depth of the experimental plots in the spring of each year for the 3-year K-fertilization rate study conducted on a Convent silt loam at Lon Mann Cotton Research Station in Marianna Arkansas from 2004-2006.

\begin{tabular}{ccccccccc}
\hline \multirow{2}{*}{ Year } & $\mathrm{pH}^{\mathrm{a}}$ & $\mathrm{NO}_{3}-\mathrm{N}^{\mathrm{b}}$ & $\mathrm{P}$ & $\mathrm{Ca}$ & $\mathrm{Mg}$ & $\mathrm{Cu}$ & $\mathrm{Zn}$ & $\mathrm{B}$ \\
\cline { 3 - 9 } & & & \multicolumn{7}{c}{$\left(\mathrm{mg}^{\mathrm{k}} \mathrm{kg}^{-1}\right)$} \\
2004 & 6.0 & 5 & 33 & 1175 & 320 & 1.5 & 2.2 & 1.3 \\
2005 & 5.9 & 8 & 40 & 1165 & 240 & 1 & 3.0 & 1 \\
2006 & 5.9 & 8 & 38 & 1258 & 261 & 1.4 & 1.9 & 2.5 \\
\hline
\end{tabular}

${ }^{\text {a}}$ Soil $\mathrm{pH}$ was measured in a 1:2 (weight: volume) soil-water mixture. ${ }^{b} \mathrm{NO}_{3}-\mathrm{N}$ measured by ion-specific electrode. 
Table 2. Analysis of variance for the effect of cotton cultivar, annual $\mathrm{K}$ fertilizer rate, and cropping year on seedcotton yield for a 3-year study conducted on a Convent silt loam at Lon Mann Cotton Research Station in Marianna, Arkansas from 2004-2006.

\begin{tabular}{ccc}
\hline Source of Variation & DF & $P$ value \\
\hline Cultivar (C) & 1 & 0.7420 \\
K-rate (KR) & 5 & 0.0005 \\
K-rate Linear & 1 & $<0.0001$ \\
K-rate Quadratic & 1 & 0.7968 \\
Year (Y) & 2 & $<0.0001$ \\
Cultivar $\times$ K-rate $(\mathrm{C} \times \mathrm{KR})$ & 5 & 0.4768 \\
Cultivar $\times$ Year $(\mathrm{C} \times \mathrm{Y})$ & 2 & 0.8146 \\
K-rate $\times$ Year $(\mathrm{Y} \times \mathrm{KR})$ & 10 & 0.5737 \\
Cultivar $\times$ K-rate $\times$ Year $(\mathrm{C} \times \mathrm{KR} \times \mathrm{Y})$ & 10 & 0.6237 \\
\hline
\end{tabular}

Pettigrew et al. [23]. In contrast Tupper et al. [24] reported that the maximal seedcotton yield of an early and late maturity cotton cultivar were produced by application of 224 and $112 \mathrm{~kg} \mathrm{~K} \mathrm{ha}^{-1} \cdot \mathrm{yr}^{-1}$ respectively and Clement-Bailey and Gwathmey [21] reported that two cotton cultivars of contrasting maturity responded differently to application of 56 and $112 \mathrm{~kg} \mathrm{~K} \mathrm{ha}^{-1} \cdot \mathrm{yr}^{-1}$. Cropping year, had similar effect on seedcotton yield response in each year, so did the cultivar as indicated by non-significant $(P>0.1)$ effects of $\mathrm{C} \times \mathrm{Y}, \mathrm{KR} \times \mathrm{Y}, \mathrm{C} \times \mathrm{KR} \times \mathrm{Y}$. These findings suggest that the seedcotton yield of the two contemporary early and late maturity cotton cultivars responded similarly to $\mathrm{K}$ fertilization and the use of a separate soil $\mathrm{K}$ calibration curve is not currently warranted. Significant year and $\mathrm{K}$-rate effects and non-significant year $\times \mathrm{K}_{2} \mathrm{O}$-rate effect observed in our study is consistent with the work of Howard et al. (2001) who observed similar trends in a 3-year study in a Memphis silt loam in Mississippi.

Potassium application rate and Y significantly influenced seedcotton yield $(P$ $\leq$ 0.0005).

Seedcotton yield response to KR were averaged across the cultivars and years, because yield was not significantly affected by the 3-way interaction of $\mathrm{C} \times \mathrm{KR} \times$ $\mathrm{Y}$ or 2-way interactions of $\mathrm{C} \times \mathrm{Y}, \mathrm{KR} \times \mathrm{Y}, \mathrm{C} \times \mathrm{KR} \times \mathrm{Y}$ (Table 3). Averaged across the 3 years the seedcotton yield of the cotton that did not received any $\mathrm{K}$ and cotton fertilized any $\mathrm{K}$ were 2940 and $3061-3438 \mathrm{~kg} \cdot \mathrm{ha}^{-1}$ indicating that $\mathrm{K}$ fertilization increased the yield $4 \%-18 \%$. Comparison of these yields with yields from earlier works by Maple and Keogh [10] where seedcotton yields ranged from $1897(0 \mathrm{~K})$ to $2160 \mathrm{~kg} \cdot \mathrm{ha}^{-1}$ with application of $84.66 \mathrm{~kg} \cdot \mathrm{ha}^{-1} \mathrm{~K}$ highlights the trend in increase in seedcotton yield in Mississippi River Delta Region during the last three decades. Trend analysis using orthogonal contrasts method indicated a significant $(P \leq 0.0001)$ linear relation between $\mathrm{K}_{2} \mathrm{O}$ application rate and seedcotton yield, but the quadratic trend was not significant (Table 2). The relation between the average annual KR and the 3-year average seedcotton yield 
Table 3. Effect of K-rate on seedcotton yield in a 3-year study conducted on a Convent silt loam at Lon Mann Cotton Research Station in Marianna, Arkansas from 2004-2006.

\begin{tabular}{cccc}
\hline $\begin{array}{c}\text { Annual } \\
\text { K-fertilizer rate } \\
\left(\mathrm{kg} \mathrm{K} \mathrm{ha}^{-1}\right)\end{array}$ & $\begin{array}{c}\text { 3-year average } \\
\text { seedcotton yield } \\
\left(\mathrm{kg} \cdot \mathrm{ha}^{-1}\right)\end{array}$ & $\begin{array}{c}\text { Cumulative } \\
(3 \text {-year }) \mathrm{K} \text { rate } \\
\left(\mathrm{kg} \mathrm{K} \mathrm{ha}^{-1}\right)\end{array}$ & $\begin{array}{c}\text { Total 3-year yield } \\
\text { seedcotton yield } \\
\left(\mathrm{kg} \cdot \mathrm{ha}^{-1}\right)\end{array}$ \\
\hline 0 & 2940 & 0 & 8720 \\
27.9 & 3061 & 83.7 & 9184 \\
55.8 & 3196 & 167.3 & 9600 \\
83.7 & 3353 & 251.0 & 10,060 \\
111.6 & 3289 & 334.7 & 9868 \\
139.4 & 3438 & 418.3 & 10,316 \\
\hline
\end{tabular}

was described by: Seedcotton yield $=2975+(3.41 \times \mathrm{KR})\left[\mathrm{R}^{2}=0.91, P<0.1\right]$. Current University of Arkansas soil test-based fertility recommendation would have prescribed an average of $66 \mathrm{~kg} \mathrm{~K} \mathrm{ha}^{-1}$ to sustain optimal cotton yield and maintain medium soil test level. Mean seedcotton yield, averaged across $\mathrm{C}$ and KR (including the $0 \mathrm{~K}$ ) was 2167, 3162, and $2627 \mathrm{~kg} \cdot \mathrm{ha}^{-1}$ in 2004, 2005 and 2006 respectively (LSD at $P=0.1=103 \mathrm{~kg} \cdot \mathrm{ha}^{-1}$ ). The higher yields of the 2005 are consistent with the results of the Arkansas Cotton Variety trials and suggest that the environmental conditions were conducive to higher seedcotton yield. The total (cumulative) 3-year seedcotton yield ranged 8720 to $10,316 \mathrm{~kg} \cdot \mathrm{ha}^{-1}$ (Table 3 ) and was significantly related to the total amount of $\mathrm{K}$ fertilizer added: Cumulative seedcotton yield $=8875+(4.01 \times \mathrm{KR})\left[\mathrm{R}^{2}=0.90, P<0.1\right]$.

\subsection{Soil-Test K}

Similar to the seedcotton yield, soil-test $\mathrm{K}$ was not affected by the $\mathrm{C}, \mathrm{C} \times \mathrm{KR}$ interaction or the three way $\mathrm{C} \times \mathrm{KR} \times \mathrm{Y}$ interaction, but it was significantly influenced by the $\mathrm{Y}$ and $\mathrm{Y} \times \mathrm{KR}$ interaction (Table 4). Therefore, the data were averaged across cultivars for each year. Post-harvest (fall) Mehlich-3 extractable soil-test $\mathrm{K}$ was significantly affected by annual $\mathrm{K}$-fertilizer rate in all years and generally increased as annual- $\mathrm{K}$ rate increased (Table 5). In 2004 and 2005, applications of $\geq 113 \mathrm{~kg} \mathrm{~K} \mathrm{ha}^{-1}$ and in 2006 application of $\geq 56 \mathrm{~kg} \mathrm{~K} \mathrm{ha}^{-1}$ significantly increased soil-test $\mathrm{K}$ compared with the unfertilized control. Potassium fertilizer rates greater and less than 28.2 to $112.9 \mathrm{~kg} \mathrm{~K} \mathrm{ha}^{-1}$ resulted in numerical decrease or increases in soil test $\mathrm{K}$ respectively. Annual application of 28.2 to $56.4 \mathrm{~kg} \mathrm{~K} \mathrm{ha}{ }^{-1}$ was needed to maintain the soil test level at or above $100 \mathrm{mg} \cdot \mathrm{kg}^{-1}$. Application of $\mathrm{K}$-fertilizer significantly and linearly $\left(P \geq 0.0082, \mathrm{R}^{2} \geq 85\right)$ increased Mehlich-3 extractable soil test $\mathrm{K}$ in fall in all years (Table 6). The slope of regression equation increased from 0.196 in 2004 to 0.554 in 2006, indicating the increasing importance of $\mathrm{K}$ fertilization in increasing soil $\mathrm{K}$ as the native supply of $\mathrm{K}$ is depleted by cropping.

Although not statistically compared, the soil-test K levels in the spring of 2006 
Table 4. Analysis of variance for the effect of cotton cultivar, annual K-fertilizer application rate, and cropping year on postharvest Mehlich-3 extractable soil test $\mathrm{K}$ in the for a 3-year study conducted on a Convent silt loam at Lon Mann Cotton Research Station in Marianna, Arkansas from 2004-2006.

\begin{tabular}{ccc}
\hline Source of Variation & DF & $P$ value \\
\hline Cultivar (C) & 1 & 0.9211 \\
K-rate & 5 & $<0.0001$ \\
K-rate Lin & 1 & $<0.0001$ \\
K-rate Quad & 1 & 0.0206 \\
K-rate Cubic & 1 & 0.6353 \\
Year & 2 & $<0.0001$ \\
Cultivar × K-rate & 5 & 0.9656 \\
Cultivar × Year & 2 & 0.2191 \\
K-rate $\times$ Year & 10 & 0.0002 \\
K-rate, yr 1 vs yr 2 Linear & 1 & 0.0218 \\
K-rate, yr 1 vs yr 2 Quadratic & 1 & 0.9755 \\
K-rate, yr 1 vs yr 3 Linear & 1 & 0.0001 \\
K-rate, yr 1 vs yr 3 Quadratic & 1 & 0.6199 \\
K-rate, yr 2 vs yr 3 Linear & 1 & 0.0520 \\
K-rate, yr 2 vs yr 3 Quadratic & 1 & 0.5985 \\
Cultivar $\times$ K-rate $\times$ Year & 10 & 0.8715 \\
\hline
\end{tabular}

Table 5. Relationship between annual and cumulative amount of $\mathrm{K}$ applied in three years and Mehlich-3 extractable $\mathrm{K}$ in the soil samples collected from the $0-15-\mathrm{cm}$ depth in the fall of each year after crop harvest.

\begin{tabular}{cccc}
\hline Year & Regression model & $\mathrm{R}^{2}$ & $P_{\text {value }}$ \\
\hline 2004 & $\mathrm{Y}=98+0.196 \mathrm{x}$ & 0.85 & 0.0079 \\
2005 & $\mathrm{Y}=82+0.390 \mathrm{x}$ & 0.97 & 0.0004 \\
2006 & $\mathrm{Y}=88+0.554 \mathrm{x}$ & 0.94 & 0.0012 \\
3-year average & $\mathrm{Y}=95+0.115 \mathrm{x}+0.002 \mathrm{x}^{2}$ & 0.99 & 0.0005 \\
2004-2006 & $\mathrm{Y}=-2.95+0.179 \mathrm{x}$ & 0.92 & 0.0029 \\
\hline
\end{tabular}

Table 6. Changes in the mean soil-test (Mehlich-3) K concentrations in the 0 - to 6-inch depth of the experimental plots during the three years of the study as affected by annual K-rate, averaged across cotton cultivars, for a K-fertilization trial on a Convent silt loam at Lon Mann Cotton Research Station in Marianna, Arkansas.

\begin{tabular}{ccccccc}
\hline \multirow{2}{*}{$\begin{array}{c}\text { K-rate } \\
(\mathrm{kg} / \mathrm{ha})\end{array}$} & Fall 2004 & Spring 2005 & Fall 2005 & Spring 2006 & Fall 2006 & Spring 2007 \\
\cline { 2 - 7 } & \multicolumn{5}{c}{ soil-test K $\left({\left.\mathrm{mg} \cdot \mathrm{kg}^{-1}\right)}\right.$} \\
\hline 0 & $105 \mathrm{a}^{\dagger}$ & $97 \mathrm{a}$ & $86 \mathrm{a}$ & $90 \mathrm{a}$ & $92 \mathrm{a}$ & $94 \mathrm{a}$ \\
28.2 & $100 \mathrm{a}$ & $97 \mathrm{a}$ & $94 \mathrm{a}$ & $97 \mathrm{a}$ & $110 \mathrm{a}$ & $111 \mathrm{~b}$ \\
56.4 & $105 \mathrm{a}$ & $110 \mathrm{a}$ & $100 \mathrm{a}$ & $111 \mathrm{a}$ & $114 \mathrm{a}$ & $108 \mathrm{~b}$ \\
84.7 & $114 \mathrm{a}$ & $110 \mathrm{a}$ & $115 \mathrm{~b}$ & $133 \mathrm{~b}$ & $133 \mathrm{~b}$ & $117 \mathrm{~b}$ \\
112.9 & $122 \mathrm{~b}$ & $122 \mathrm{~b}$ & $125 \mathrm{~b}$ & $147 \mathrm{~b}$ & $147 \mathrm{~b}$ & $131 \mathrm{c}$ \\
141.1 & $130 \mathrm{~b}$ & $132 \mathrm{~b}$ & $146 \mathrm{c}$ & $169 \mathrm{c}$ & $182 \mathrm{c}$ & $159 \mathrm{~d}$ \\
$P$ value & $<0.0001$ & 0.0002 & $<0.0001$ & $<0.0001$ & $<0.0001$ & $<0.0001$ \\
\hline
\end{tabular}

${ }^{\dagger}$ Means followed by the same letter were not significantly different at $P=0.1$. 
were numerically and consistently higher than the fall of 2005 suggesting possible $\mathrm{K}$ release from crop residue and/or labile soil pool. Using the soil-test $\mathrm{K}$ data from the spring of 2007, we estimated the increase in soil-test $\mathrm{K}$ at each $\mathrm{K}$ rate by subtracting the mean soil-test $\mathrm{K}$ (at that rate) from that of the unfertilized check. Cumulative application of 84 to $419 \mathrm{~kg} \mathrm{~K} \mathrm{ha}^{-1}$ in three years, increased the soil-test $\mathrm{K}$ by $14-67 \mathrm{mg} \mathrm{K} \mathrm{kg}{ }^{-1}$ respectively despite $\mathrm{K}$ removal by three crops of cotton.

\section{Conclusions}

A 3-year replicated field experiment was conducted on a Convent silt loam to evaluate the effect of K-fertilizer rate $(0,28.2,56.4,84.7,112.9$, and $141.1 \mathrm{~kg} \mathrm{~K}$ $\mathrm{ha}^{-1} \mathrm{~K}$ ) and cotton cultivar (a short and a long season) on seedcotton yield and soil. Potassium fertilizer treatments were applied to the same plots each year. Seedcotton yields were not affected by higher order interactions involving cropping year and/or cultivar and K-rate. Annual K-fertilizer significantly increased the seedcotton yield in the second and third year. The 3-year average, and cumulative seedcotton yield was significantly and linearly increased by annual $\mathrm{K}$ application. Both short and long season cultivars responded similarly to $\mathrm{K}$ application. Mehlich-3 extractable soil-test $\mathrm{K}$ was not affected by the cultivar or cultivar $\times \mathrm{K}$ rate interaction in any year, indicating that the cultivars had similar effect on Mehlich-3 extractable and petiole-K. Mehlich-3 extractable soil-test K in the fall of each year was significantly and linearly increased by $\mathrm{K}$ fertilization. Application of $0.83 \mathrm{~kg} \mathrm{~K}_{2} \mathrm{O} \mathrm{ha}{ }^{-1}$ increased Mehlich-3 extractable soil test $\mathrm{K}$ by $0.34 \mathrm{mg} \cdot \mathrm{kg}^{-1}$.

The results from this 3-year study support the current University of Arkansas $\mathrm{K}$ fertilization guidelines for irrigated cotton production in silt loam soils. Future field studies should focus on correlation and calibration of Mehlich-3 extractable $\mathrm{K}$ for modern cotton production practices.

\section{References}

[1] Arkansas Agricultural Statistics Service. (2017) Cotton Yield and Production. https://www.nass.usda.gov/Quick_Stats/Lite/index.php

[2] Mullins, G.L. and Burnester, C.H. (1997) Potassium Uptake by Crops during the Season. In: Oosterhuis, D.M. and Berkowitz, G.A., Eds., Frontiers in Potassium $\mathrm{Nu}$ trition: New Perspectives on the Effects of Potassium on Physiology of Plants, Proceedings of a Symposium Sponsored by Potash \& Phosphate Institute and the Crop Science Society of America, Norcross, GA, November 1996, 123-132.

[3] Hodges, S.C. and Constable, G. (2010) Plant Response to Mineral Deficiency and Toxicities. In: Stewart, J.M., Oosterhuis, D.M., Heitholt, J.J. and Mauney, J.R., Eds., Physiology of Cotton, Springer Science, London, 142-162.

[4] Humble, G.D. and Raschke, K. (1971) Stomatal Opening Quantitatively Related to Potassium Transport. Plant Physiology, 48, 447-453.

https://doi.org/10.1104/pp.48.4.447

[5] Dong, H.Z., Tang, W., Li, Z.H. and Zhang, D.M. (2004) On Potassium Deficiency in 
Cotton-Disorder, Cause and Tissue Diagnosis. Agriculture Conspectrus Scientificus, 69, 77-85.

[6] Bendarez, C.W. and Oosterhuis, D.M. (1999) Physiological Changes Associated with Potassium Deficiency in Cotton. Journal of Plant Nutrition, 22, 303-313.

[7] Oosterhuis, D.M., Loka, D.A., Kawakami, E.M. and Pettigrew, W.T. (2014) The Physiology of Potassium in Crop Production. In: Sparks, D.L., Ed., Advances in Agronomy, Academic Press, 203-233.

[8] Cope Jr., J.T. (1981) Effect of 50 Years of Fertilization with Phosphorus and Potassium on Soil Test Levels and Yields at Six Locations. Soil Science Society of America Journal, 45, 342-347. https://doi.org/10.2136/sssaj1981.03615995004500020023x

[9] Pettigrew, W.T., Heitholt, J.J. and Meredith Jr., W.R. (1996) Genotypic Interactions with Potassium and Nitrogen in Cotton of Varied Maturity. Agronomy Journal, 88, 89-93. https://doi.org/10.2134/agronj1996.00021962008800010019x

[10] Maple, R. and Keogh, J.L. (1974) Fertilization of Cotton with Potassium, Magnesium, and Sulfur on Certain Delta Soils. University of Arkansas, Fayetteville, Arkansas.

[11] Howard, D.D., Essington, M.E., Hayes, R.M. and Percel, W.M. (2001) Potassium Fertilization of Conventional and No-Till Cotton. Journal of Cotton Science, 5, 197-205.

[12] USDA NASS. (2017) Agricultural Chemical Usage, Field Crops Summary. https://www.nass.usda.gov/Quick_Stats/Lite/result.php?34631837-396F-3EFF-97689D49762DFF8E

[13] Decamberato, J.J. And Jones, M.A. (2005) Differences in Potassium Requirement and Response by Older and Modern Cotton Varieties. Better Crops, 89, 18-20.

[14] Pace, P.F., Cralle, H.T., Cothren, J.T. and Senseman, S.A. (1999) Photosynthesis and Dry Matter Portioning in Short and Long-Season Cotton Cultivars. Crop Science, 39, 1065-1069. https://doi.org/10.2135/cropsci1999.0011183X003900040018x

[15] Sikora F.J. and Moore, K.P. (2015) Soil Testing Methods from the Southern United States. http://aesl.ces.uga.edu/sera6/PUB/MethodsManualFinalSERA6.pdf

[16] Arshad, M.A., Lowery, B. and Grossman, B. (1996) Physical Tests for Monitoring Soil Quality. In: Doran, J.W. and Jones, A.J., Eds., Methods for Assessing Soil Quality, SSSA Spec. Publ. 49, SSSA, Madison, 23-141.

[17] University of Arkansas Cooperative Extension Service (2017) Irrigation Scheduler. https://irrigweb.uaex.edu/

[18] Espinoza, L., Mozaffari, M. and Slaton, N.A. (2006) Soil Testing, Lime and Fertilizer Recommendations Handbook. MP463-11-06N. University of Arkansas Division of Agriculture, University of Arkansas Cooperative Extension Service Printing Services, Little Rock.

[19] Mullins, G.L. and Burmester, C.H. (1991) Dry Matter, Nitrogen, Phosphorus, and Potassium Accumulation by Four Cotton Varieties. Agronomy Journal, 82, 729-736.

[20] Arkansas Variety Testing Program. http://www.arkansasvarietytesting.com/home/cotton/

[21] Clement-Bailey, J. and Gwathmey, C. (2007) Potassium Effects on Portioning, Yield and Earliness of Contrasting Cotton Cultivars. Agromomy Journal, 99, 1130-1136. https://doi.org/10.2134/agronj2006.0288

[22] Pettigrew, W.T. and Meredith, W.R. (1997) Dry Matter Production, Nutrient Up- 
take, and Growth of Cotton as Affected by Potassium Fertilization. Journal of Plant Nutrition, 20, 531-548. https://doi.org/10.1080/01904169709365272

[23] Pettigrew, W.T., Meredith, W.R. and Young, L.D. (2005) Potassium Fertilization Effects on Cotton Lint Yield, Yield Components, and Reniform Nematode Populations. Agronomy Journal, 97, 1245-1251. https://doi.org/10.2134/agronj2004.0321

[24] Tupper, G.R., Calhoun, D.S. and Ebelhar, M.W. (1996) Sensitivity of Early Maturing Varieties to Potassium Deficiency. In: Dugger, P. and Richter, D., Eds., Proceedings of Beltwide Cotton Conference, National Cotton Council, Memphis, 625-628. 